\title{
Characterization of Aeromonas sobria Isolated from Fish Rohu (Labeo rohita) Collected from Polluted Pond
}

\author{
Gowhar H Dar ${ }^{1,2^{*}}$, Azra N Kamili ${ }^{2}$, Mohammad Z Chishti ${ }^{3}$, Shoaib A Dar ${ }^{3}$, Towsief A Tantry ${ }^{2}$ and Fayaz Ahmad ${ }^{2}$ \\ ${ }^{1}$ Department of Environmental Science, University of Kashmir, Srinagar 190006, India \\ ${ }^{2}$ Centre of Research for Development, University of Kashmir, Srinagar190006, India \\ ${ }^{3}$ Department of Zoology, Punjabi University, Patiala 147002, India
}

"Corresponding author: Gowhar H Dar, Department of Environmental Science, University of Kashmir, Srinagar 190006, India, Tel:+91-9797124446; E-mail: dargowharhamid@gmail.com

Received date: April 07, 2016; Accepted date: April 29, 2016; Published date: May 05, 2016

Copyright: ( 2016 Dar GH, et al. This is an open-access article distributed under the terms of the Creative Commons Attribution License, which permits unrestricted use, distribution, and reproduction in any medium, provided the original author and source are credited.

\begin{abstract}
One of the major threats to fish aquaculture sector is the infection by Aeromonas Spp. The current study assesses the phenotypic characteristics and biochemical characterization of the $A$. sobria strains from the fish cases with septicaemia in order to understand the frequency and occurrence of this infection in the state of Jammu and Kashmir. Clinically the infected fish Rohu (Labeo rohita), one of the Indian Major carps (IMC), was observed for symptoms like loss of escape reflex and skin darkness associated with skin haemorrhages. We isolated 30 colonies of $A$. sobria strain from 10 cultured Labeo rohita collected from a controlled fish pond in District Poonch of the state. The pond was affected by mismanagement practices, elevated pollution levels and anthropogenic activities. Microscopic examination revealed that the strain was rod-shaped and gram negative. The revealed percent probability identification of $A$. sobria from the biochemical characterization in Vitek system was $93 \%$ with $\mathrm{GN}$ card. This study could give us clues for understanding $A$. sobria harbouring in fish species and shall help in better understanding of the threat prevalent to the fish species of the region by this infection.
\end{abstract}

Keywords: Labeo rohita; Indian Major Carp (IMC); Aeromonas sobria; Characterization; Vitek-2 system

\section{Introduction}

Aeromonas species can cause infections not only in humans but in fish as well, isolated frequently from surface waters, estuarine water, fresh water, food products, sewage, diseased or healthy fish, human and animal excreta, are ubiquitous in aquatic ecosystems [1-5]. Infections of these types are perhaps the most widespread due to bacterial diseases diagnosed in cultured warm water fish [6,7]. Aeromonas species are of no interest in food because at ambient temperature, they are known as active spoilers of fish and meat $[8,9]$. These species are known to be opportunistic pathogens for fish and generally the incidence rate of this disease is linked to stress conditions such as overcrowding (because of Polyculture), poor water quality, or rough handling and can cause major epidemic outbreaks $[2,10,11]$ and are straight nonspore-forming rods, Gram-negative, normally facultative anaerobic, cytochrome oxidase positive, chemoorganotrophic and usually characterized by being capable to grow at $0 \% \mathrm{NaCl}$ but not at $6 \% \mathrm{NaCl}$ [2]. Taxonomically, the genus Aeromonas belongs to the class Gammaproteobacteria, order Aeromonadales and family Aeromonadaceae [12].

Aeromonas septicaemia is a critical contagious disease of coldblooded animals and humans $[13,14]$ and is frequently caused by the motile Aeromonas, particularly A. hydrphila, A. caviae and A. sobria. Aeromonas species are facultative anaerobic Gram-negative bacteria and are psychrophilic and mesophilic in nature $[13,15]$. The release of two important virulence factors namely extracellular hemolysin and aerolysin potentially contribute to the occurrence of septicaemia $[6,7]$. To identify these bacteria, numerous biochemical schemes have been proposed [16] and some papers reported that the Vitek GN card could be useful in identification of bacteria within the genus Aeromonas [17].

The objectives of this study were to focus on the isolation and identification of the strains of Aeromonas from the cases of septicaemia in fishes of Jammu and Kashmir State for the first time and develop some understanding regarding the distribution of this infection in fishes of this part of the world.

\section{Material and Methods}

\section{Sampling of Rohu (Labeo rohita) fish}

The Rohu (Labeo rohita) specimens obtained from the fish pond at District Poonch of Jammu and Kashmir state were collected in the month of December 2013, with a cast net and identified by the help of various taxonomic keys $[18,19]$. Help was also sought from from the local experts in the field. It is one of the most extensively cultured Indian Major Carps (IMC). Out of 20 fishes collected, 3 were found to be infected with $A$. sobria. Therefore, the prevalence rate was found to be $(15 \%)$. Body weights of the collected specimens ranged from $50 \pm$ $10 \mathrm{~g}$.

\section{Assessment of morphological/clinical pathological symptoms}

Collected specimens were carefully examined for symptoms of diseases with special focus towards the lesions on the skin [20]. Rohu (Labeo rohita) was assessed for bacterial infection by observing the following symptoms: pale gills indicative of anaemia, exophthalmia, abdominal distension, skin blisters, shallow ulcers, haemorrhages and 
intramuscular cavities filled with blood-tinged caseous or necrotic material [17]. The surface of the skin was showing red rashes on the body along with ulceration. External surface skin swabs from the samples were inoculated onto the nutrient agar (NA) medium for culturing bacteria [21].

\section{Isolation and identification of $\boldsymbol{A}$. sobria}

Isolation of fish pathogenic bacteria was carried out by culture dependent approach and for this purpose spread plating technique was used. The surface of the fish was swabbed for bacteria isolation, and the inoculums were spread over nutrient-rich medium i.e. nutrient agar medium $[17,22]$, with incubation at $25^{\circ} \mathrm{C}-30^{\circ} \mathrm{C}$ for $2-3$ days [23-25]. The purified stocks of the bacterial strains were obtained and stored for further morphological and biochemical identification.

\section{Morphological characterization}

The bacterial films were prepared from each purified isolate and thereafter Gram's staining was carried [26]. The slides were examined under the bright field microscope with oil immersion lens.

\section{Biochemical characterization}

The characterization of bacteria is carried phenotypically and a wealth of knowledge is available on the phenotypic characteristics of the microbes. Though in recent times, emphasis towards molecular based approaches has increased and phenotypic approach has declined. But, nevertheless, in polyphasic studies whereby many facts of the biology of an organism are studied, phenotypic data has a role [27]. Biochemical identification and characterization of the isolated A. sobria was carried out using the VITEK 2 system which is based on 47 biochemical and physiological test reactions (Table 1). The VITEK 2 compact system is a fully automated system that performs bacterial identification by biochemical analysis using colorimetry. VITEK 2 system automatically performs all of the steps required for identification of bacteria. This system allows kinetic analysis by reading each test every $15 \mathrm{~min}$. The optical system combines multichannel fluorimeter and photometer readings to record fluorescence, turbidity, and colorimetric signals [12].

\begin{tabular}{|c|c|c|c|c|c|}
\hline APPA & Alla-phe-pro-ARYLAMIDASE & ADO & ADONITOL & PyrA & L-Pyrrolydonyl-ARYLAMIDASE \\
\hline IARL & L-ARABITOL & dCEL & D-CELLOBIOSE & BGAL & BETA-GALACTOSIDASE \\
\hline $\mathrm{H} 2 \mathrm{~S}$ & H2S PRODUCTION & BNAG & $\begin{array}{l}\text { BETA-N-ACETYL- } \\
\text { GLUCOSAMINIDASE }\end{array}$ & AGLTp & Glutamyl Arylamidase pNA \\
\hline dGLU & D-GLUCOSE & GGT & $\begin{array}{l}\text { GAMA-GLUTAMYL- } \\
\text { TRANSFERASE }\end{array}$ & OFF & FERMENTATION/GLUCOSE \\
\hline BGLU & BETA-GLUCOSIDASE & DMAL & D-MALTOSE & dMAN & D-MANNITOL \\
\hline dMNE & D-MANNOSE & BXYL & BETA-XYLOSIDASE & BALap & BETA-Alanine arylamidase pNA \\
\hline ProA & L-Proline ARYLAMIDASE & LIP & LIPASE & PLE & PALATINOSE \\
\hline TyrA & Tyrosine ARYLAMIDASE & URE & UREASE & dSOR & D-SORBITOL \\
\hline SAC & SACCHAROSE/SUCROSE & dTAG & D-TAGATOSE & dTRE & D-TREHALOSE \\
\hline CIT & CITRATE(SODIUM) & MNT & MALONATE & $5 K G$ & 5-KETO-D-GLUCONATE \\
\hline ILATK & L-LACTATE alkalinisation & AGLU & ALPHA-GLUCOSIDASE & SUCT & SUCCINATE alkalinisation \\
\hline NAGA & $\begin{array}{l}\text { Beta-N-ACETYL- } \\
\text { GALACTOSAMANIDASE }\end{array}$ & AGAL & ALPHA-GALACTOSIDASE & PHOS & PHOSPHATE \\
\hline GLyA & Glycine ARYLAMIDASE & ODC & ORNITHINE DECARBOXYLASE & LDC & LYSINE DECARBOXYLASE \\
\hline IHISa & L-HISTIDINE assimilation & СMT & COUMARATE & BGUR & BETA-GLUCORONIDASE \\
\hline O129R & 0/129 RESISTANCE & GGAA & Glu-Gly-Arg-ARYLAMIDASE & IMLTa & L-MALATE assimilation \\
\hline ELLM & ELLMAN & ILATa & L-LACTATE assimilation & & \\
\hline
\end{tabular}

Table 1: Details of biochemical Tests carried in Vitek-2 System.

\section{Results}

The clinical examination of diseased fish reveals the presence of red spots on the body. Ulceration was also spotted on the body of fish. Isolation of bacteria was achieved by swabbing the surface of the fish and then followed by inoculation of bacterial strain on nutrient-rich medium, such as nutrient agar medium (NA) with incubation at $25^{\circ} \mathrm{C}-30^{\circ} \mathrm{C}$ for $2-3$ days. Different types of colonies were obtained during the study period. Some colonies were circular in shape and some irregular, few colonies were Rhizoid and filamentous. A total of 30 colonies of the $A$. sobria strain were completely counted on nutrient agar media plates. The colonies of $A$. sobria were creamy in color and morphologically they were circular in appearance, entire in margin and were having flat elevation. Creamy colonies were selected and restreaked three times onto fresh media to obtain pure isolates. The Strain was observed under microscope for cell shape and it was found to be rod in shape and it gave Grams negative reaction upon Gram 
Page 3 of 5

staining. In this study, the isolated bacterium was found to be gram negative, and the results of the isolate from the database of Vitek system on GN card showed that the percent probability of identification of $A$. sobria was $93 \%$. Biochemical identification results and characterization observations made on this strain in VITEK- 2 system with 47 tests are indicated in Table 2.

\begin{tabular}{|c|c|c|c|c|c|c|c|c|}
\hline Well & Mnemonic & Reaction & Well & Mnemonic & Reaction & Well & Mnemonic & Reaction \\
\hline 2 & APPA & + & 3 & ADO & - & 4 & PyrA & $(+)$ \\
\hline 5 & IARL & - & 7 & dCEL & + & 9 & BGAL & + \\
\hline 10 & $\mathrm{H} 2 \mathrm{~S}$ & - & 11 & BNAG & + & 12 & AGLTp & - \\
\hline 13 & dGLU & + & 14 & GGT & - & 15 & OFF & + \\
\hline 17 & BGLU & _- & 18 & Dmal & + & 19 & dMAN & + \\
\hline 20 & dMNE & + & 21 & BXYL & - & 22 & BALap & - \\
\hline 23 & ProA & + & 26 & LIP & - & 27 & PLE & - \\
\hline 29 & TyrA & + & 31 & URE & $(-)$ & 32 & dSOR & _ \\
\hline 33 & SAC & + & 34 & Dtag & _ & 35 & dTRE & + \\
\hline 36 & CIT & + & 37 & MNT & - & 39 & $5 K G$ & - \\
\hline 40 & ILATK & - & 41 & AGLU & - & 42 & SUCT & + \\
\hline 43 & NAGA & + & 44 & AGAL & + & 45 & PHOS & - \\
\hline 46 & GLyA & _ & 47 & ODC & - & 48 & LDC & - \\
\hline 53 & IHISa & - & 56 & CMT & + & 57 & BGUR & - \\
\hline 58 & O129R & + & 59 & GGAA & $(-)$ & 61 & IMLTa & + \\
\hline 62 & ELLM & $(-)$ & 64 & ILATa & - & & & \\
\hline
\end{tabular}

Table 2: Biochemical Details of Aeromonas sobria on test substrates on GN Card.

\section{Discussion}

Aquaculture sector is under a persistent threat due to fish pathogen Aeromonas spp. Biochemical studies like the ones discussed here are important in the search for alternative and more effective methods of control of these fish pathogens. Mismanagement practices, elevated pollution levels and anthropogenic activities often trigger the Aeromonas infections in fish in aquaculture. The fish pond explored during the present study was affected by all these parameters. Fishes in aquaculture are prone to a variety of diseases due to inapt farm management systems, so vulnerability of fish to pathogenic infections is enhanced [28] and diversity of mobile Aeromonas Spp. has been reported in the aquatic environment and fish [29-31]. The exposure of the fish pond to human and other activities might have induced some pollution activities into the aquatic environment of the pond and scattering of pathogenic $A$. sobria into the aquatic environment by excreta material can pollute not only fish fauna but also other fauna harvested from these waters and once these bacteria are in the aquatic environment, plasmid exchange between the bacteria is readily facilitated and can result in a higher frequency of multiple antibiotic resistant strains and the development of fish disease in the fish [32]. Usage of medicated feeds in agriculture sector and their application to the rapidly developing fish and shellfish farming [33] can result in the production of virulent and resistant bacterial pathogens in the natural environment and thus potentially into the human food chain, which may have also prompted for the breakout of Aeromonas infection in the water body studied during the present study. Aeromonas species causes septicaemia with widespread skin lesions and affecting internal organs such as liver, spleen and muscles. Infected fish obtained revealed the presence of red rashes on the body. Similar observations were recorded by $[17,20]$ who mentioned that the infection created by Aeromonas Spp could be the cause of skin ulcers in fishes. Characteristic colonies of $A$. sobria on Nutrient Agar medium were indicated by creamy colonies and the results obtained agree with the findings of some authors who mentioned that the color of bacterial colony could be a diagnostic factor to ascertain its genus level $[17,34]$. The morphological results and biochemical tests of a total of 30 strains of $A$. sobria were carried out which established the species level of the isolated bacterial species. Similar results were reported by various authors, who mentioned that $A$. sobria was most commonly isolated Spp. from apparently healthy fishes and suggest that the morphological and biochemical characteristic results could be diagnostic tools to identify the bacterial species $[35,36]$. During this study, the isolated bacterium was found to be gram negative, and showed $93 \%$ probability using the Vitek System. Edwardsiella tarda indicated $98 \%$ probability in Vitek System 2 test which is in consonance with the present study [37]. Similarly, the results from the Vitek database indicated that the percent probabilities of identification of $A$. veronii were 95 to $99 \%$, however the percent probabilities of identification of $A$. hydrophila, $A$. caviae and A. sorbia were only 69 to $83 \%$ [38] and $A$. sobria was $93 \%$ [17]. 


\section{Conclusion}

The study revealed the presence of $A$. sobria in Rohu Labeo rohita from aquaculture farm at Poonch $\mathrm{J} \& \mathrm{~K}$, India. The revealed percent probability identification of $A$. sobria from the biochemical characterization in Vitek system was $93 \%$ with GN card. The study highlights the diversity of $A$. sobria that could potentially be associated with skin surfaces of the fish and trigger infections. The results obtained highlight the need to promote responsible fish ownership, good husbandry practices and prudent use of antimicrobials in the fish industry so as to control this type of infection.

\section{Acknowledgements}

The authors would like to thank Department of Science and Technology (DST), Govt. of India and Govt. of Jammu and Kashmir Department of Fisheries for financial assistance. The authors are also thankful to Dr Qadris Haematology Centre, Srinagar for identification of bacterial strains. This work coincides with partial fulfillment of $\mathrm{PhD}$ dissertation of principal author (GHD).

\section{References}

1. Khardori N, Fainstein V (1988) Aeromonas and Plesiomonas as etiological agents. Annu Rev Microbiol 42: 395-419.

2. Beaz-Hidalgo R, Figueras MJ (2013) Aeromonas spp. whole genomes and virulence factors implicated in fish disease. J Fish Dis 36: 371-388.

3. Janda JM (2001) Aeromonas and Plesiomonas. In: Molecular Medical Microbiology (ed. by M. Sussman). Academic Press, San Diego, CA. pp. 1237-1270.

4. Figueras MJ (2005) Clinical relevance of Aeromonas sM503. Reviews in Medical Microbiology 16: 145-153.

5. Janda JM, Abbott SL (2010) The genus Aeromonas taxonomy, pathogenicity, and infection. Clin Microbiol Rev 23: 35-73.

6. Chopra AK, Houston CW, Peterson JW, Jin GF (1993) Cloning, expression, and sequence analysis of a cytolytic enterotoxin gene from Aeromonas hydrophila. Can J Microbiol 39: 513-523.

7. Nordmann P, Poirel L (2002) Emerging carbapenemases in Gramnegative aerobes. Clin Microbiol Infect 8: 321-331.

8. Popoff M (1984) Genus III Aeromonas. In: Kluyver AJ, Van Niel CJ Bergey's Manual of Systematic Bacteriology, vol. 1. Williams and Wilkins, Baltimore, MD. Pp: 545-548.

9. Gram L, Oundo JO, Bon J (1989) Storage life of Nile perch (Lates niloticus) in relation to temperature and initial bacterial load. Trop Sci 29: 221-236.

10. Bernoth E (1990) Autoagglutination, growth on tryptonesoy-Coomassie agar, outer membrane protein patterns and virulence of Aeromonas salmonicida strain. Journal of Fish Microbiology 41: 2348-2357.

11. Noga EJ (2010) Fish Diseases: Diagnosis and Treatment (2nd edn.). Willey-Blackwell, Singapore.

12. Ligozzi M, Bernini C, Bonora MG, De Fatima M, Zuliani J, et al. (2002) Evaluation of the VITEK 2 system for identification and antimicrobial susceptibility testing of medically relevant gram-positive cocci. J Clin Microbiol 40: 1681-1686.

13. Austin B, Austin DA (1987) Bacterial fish pathogens: disease in farmed and wild fish. Halsted Press, New York.

14. Dryden M, Munro R (1989) Aeromonas septicemia: relationship of species and clinical features. Pathology 21: 111-114.

15. Areerat S (1987) Clarias culture in Thailand. Aquaculture 63: 355-362.

16. Abbott SL, Cheung WK, Janda JM (2003) The genus Aeromonas: biochemical characteristics, atypical reactions, and phenotypic identification schemes. J Clin Microbiol 41: 2348-2357.

17. Dar GH, Dar SA, Kamili AN, Chishti MZ, Ahmad F (2016) Detection and characterization of potentially pathogenic Aeromonas sobria isolated from fish Hypophthalmichthys molitrix (Cypriniformes: Cyprinidae). Microbial Pathogenesis 91: 136-140.

18. Jhingram VG (2007) Fish and Fisheries of India. Hindustan publishing corporation (India).

19. Tilak R (1987) The fauna of India. Zoological survey of India, New Delhi.

20. Noor El Deen AE, Dorgham SM, Hassan AHM, Hakim AS (2014) Studies on Aeromonas hydrophila in Cultured Oreochromis niloticus at Kafr El Sheikh Governorate, Egypt with Reference to Histopathological Alterations in Some Vital Organs. World Journal of Fish and Marine Sciences 6: 233-240.

21. Austin B, Austin DA (2012) Bacterial fish pathogens: Disease of farmed and wild fish (3rd edition). pp: 112-115.

22. Spanggaard B, Huber I, Nielsen J, Nielsen T, Appel KF, et al. (2000) The microflora of rainbow trout intestine: A comparison of traditional and molecular identification. Aquaculture 182: 1-15.

23. Eddy SD, Jones SH (2002) Microbiology of the summer flounder Paralichthys dentatus fingerling production at a marine fish hatchery. Aquaculture 211: 9-28.

24. Al-Harbi AH, Uddin MN (2004) Seasonal variation in the intestinal bacterial flora of hybrid tilapia (Oreochromis niloticus $\mathrm{x}$ Oreochromis aureus) cultured in earthern ponds in Saudi Arabia. Aquaculture. 229: 37-44.

25. Al-Harbi AH, Uddin N (2005) Bacterial diversity of tilapia (Oreochromis niloticus) cultured in brackish water in Saudi Arabia. Aquaculture 250 566-572.

26. Cruickshank R, Duguid JP, Marmian BP, Swain RHA (1979) Medical Microbiol. The practice of medical Microbiol (12thed) Churchill Livingstone, Edinburgh, London.

27. Vandamme P, Pot B, Gillis M, de Vos P, Kersters K, et al. (1996) Polyphasic taxonomy, a consensus approach to bacterial systematics. Microbiol Rev 60: 407-438.

28. El-Sayed AFM (2006) Stress and diseases. In: Tilapia Culture (El-Sayed AFM. ed.), CABI Publishing, Cambridge. Pp: 149-151.

29. Kaper JB, Lockman H, Colwell RR, Joseph SW (1981) Aeromonas hydrophila: ecology and toxigenicity of isolates from an estuary. J App Bacteriol 50: 359-377.

30. Carlos A, Kaysner CA, Wekell MM, Sullivan JJ, Stelma GN (1986) Recovery of Aeromonas hydrophila from oysters implicated in an outbreak of food borne illness. J Food Prot 49: 643- 650

31. Hatha M, Vivekanandhan AA, Joice GJ, Christol (2005) Antibiotic resistance pattern of motile aeromonads from farm raised fresh water fish. Int J Food Microbiol 98: 131-134.

32. Chang BJ, Bolton SM (1987) Plasmids and resistance to antimicrobial agents in Aeromonas hydrophila clinical isolates. Antimicrob Agents Chemother 31: 1281-1282.

33. Redmayne PC (1989) World aquacultural developments. Food Technol 43: 80-86.

34. Hazen TC, Fliermans CB, Hirsch RP, Esch GW (1978) Prevalence and distribution of Aeromonas hydrophila in the United States. Appl Environ Microbiol 36: 731-738.

35. Santos Y, Toranzo AE, Barja JL, Nieto TP, Villa TG (1988) Virulence properties and enterotoxin production of Aeromonas strains isolated from fish. Infect Immun 56: 3285-3293.

36. Rathore G, Swaminathan TR, Abidi R, Mahanta PC, Kapoor D (2005) Isolation and characterization of motile aeromonads from aquatic environment. Ind J Fish 52: 241-248.

37. Choresca Jr CH, Gomez DK, Shin SP, Kim JH, Han JE, et al. (2011) Molecular detection of Edwardsiella tarda with gyrB gene isolated from pirarucu, Arapaima gigas which is exhibited in an indoor private commercial aquarium. African Journal of Biotechnology 10: 848-850.

38. Cai SH, Wu ZH, Jian JC, Lu YS, Tang JF (2012) Characterization Of Pathogenic Aeromonas Veronii Bv. Veronii associated with Ulcerative Syndrome From Chinese Longsnout Catfish (Leiocassis Longirostris Günther). Braz J Microbiol 43: 382-388. 